\title{
Profitabilitas, Kecukupan Modal, Leverage dan Nilai Perusahaan dengan Pengungkapan Islamic Social Reporting sebagai Variabel Moderating
}

\author{
Septi Tunjungsari ${ }^{1}$ \\ Fakultas Ekonomi dan Bisnis Islam \\ IAIN Salatiga, Indonesia
}

\author{
Nafis Irkhami ${ }^{2}$ \\ Fakultas Ekonomi dan Bisnis Islam \\ IAIN Salatiga, Indonesia
}

\begin{abstract}
Surel: stunjungsari33@gmail.com
ABSTRAK

Tujuan penelitian adalah untuk mengetahui pengaruh profitabilitas, kecukupan modal, dan leverage terhadap nilai perusahaan dengan Islamic Social Reporting (ISR) sebagai variabel moderating. Populasi data penelitian iniadalah BUS diIndonesia periode 2014-2019. Metode pengambilan sampel purposive sampling yaitu menggunakan beberapa kriteria sehingga terdapat 11 BUS yang menjadi sampel penelitian. Data diolah menggunakan regresilinier berganda dengan bantuan Eviews 10. Hasil penelitian menunjukkan ROA berpengaruh positif signifikan terhadap nilai perusahaan, sedangkan ROE berpengaruh negatif signifikan terhadap nilai perusahaan. CAR dan leverage tidak berpengaruh signifikan terhadap nilai perusahaan. ISR tidak mampu memoderasi CAR dan leverage terhadap nilai perusahaan, sedangkan ROA, ROE mampu dimoderasi ISR terhadapnilai perusahaan.
\end{abstract}

Kata Kunci: Profitabilitas; ROA; ROE; CAR; Leverage; ISR.

\section{Profitability, Capital Adequacy, Leverage and Firm Value with Islamic Social Reporting Disclosures as Moderating Variables}

\section{ABSTRACT}

The purpose of this study was to determine the effect of profitability, capital adequacy, and leverage on firm value with Islamic Social Reporting (ISR) as a moderating variable. The population of this research data is BUS in Indonesia for the period 2014-2019. The sampling method is purposive sampling, which uses several criteria so that there are 11 BUS as the research sample. The data were processed using multiple linear regression with the help of Eviews 10. The results showed that ROA had a significant positive effect on firm value, while ROE had a significant negative effect on firm value. CAR and leverage have no significant effect on firm value. ISR is not able to moderate CAR and leverage to firm value, while ROA and ROE are able to moderate ISR to firm value.

Keywords: Profitability;ROA; ROE; CAR; Leverage; ISR.

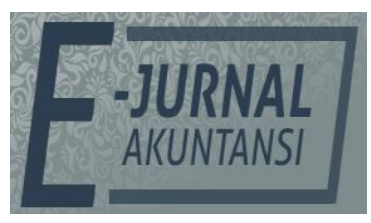

e-ISSN 2302-8556

Vol. 31 No. 11

Denpasar, November 2021

Hal. 2677-2692

DOI:

10.24843/EJA.2021.v31.i11.p01

PENGUTIPAN:

Tunjungsari, S., \& Irkhami, N.

(2021). Profitabilitas,

Kecukupan Modal, Leverage dan Nilai Perusahaan dengan

Pengungkapan Islamic Social Reporting sebagai Variabel Moderating. E-Jurnal Akuntansi, 31(11), 2677-2692

RIWAYAT ARTIKEL:

Artikel Masuk:

31 Mei 2021

Artikel Diterima: 24 November 2021

Artikel dapat diakses: https://ojs.unud.ac.id/index.php/Akuntansi/index 


\section{PENDAHULUAN}

Kondisi perekonomian saat ini telah menciptakan persaingan yang ketat antar perusahaan di industri tersebut. Persaingan ini membuat setiap perusahaan semakin meningkatkan kinerjanya untuk mencapai tujuannya. Tujuan perusahaan adalah tujuan jangka pendek dan jangka panjang. Tujuan jangka pendek adalah memungkinkan perusahaan menggunakan sumber daya perusahaan untuk memaksimalkan keuntungan, sedangkan tujuan jangka panjang adalah memaksimalkan nilai perusahaan. Optimalisasi nilai perusahaan dapat dicapai dengan menerapkan fungsi manajemen keuangan, dimana satu keputusan keuangan akan mempengaruhi keputusan keuangan lainnya dan mempengaruhi nilai perusahaan. Biasanya tujuan pengambilan keputusan keuangan adalah untuk memaksimalkan nilai perusahaan atau kekayaan pemegang saham. Nilai perusahaan adalah harga yang bersedia dibayar oleh calon pembeli saat perusahaan tersebut dijual. Semakin tinggi nilai perusahaan maka semakin besar kemakmuran yang akan diterima pemilik perusahaan (Wiksuana \& Wulandari, 2017).

Pengukuran kinerja perusahaan merupakan salah satu indikator yang digunakan investor untuk mengevaluasi perusahaan. Semakin baik kinerja perusahaan maka semakin tinggi pula return yang didapatkan oleh investor. Jika perusahaan menikmati reputasi yang baik maka capital gain dan nilai perusahaan akan meningkat, yang tercermin dalam laporan keuangannya. Dalam penelitian ini profitabilitas yang digunakan yaitu Return on Asset (ROA) dan Return on Equity (ROE), rasiol kecukupan modal atau Capital Adequacly Ratio (CAR) dan rasio Leverage. Dapat dilihat pada grafik petumbuhan Bank Umum Syariah Indonesia pada sektor keuangan berikut ini.

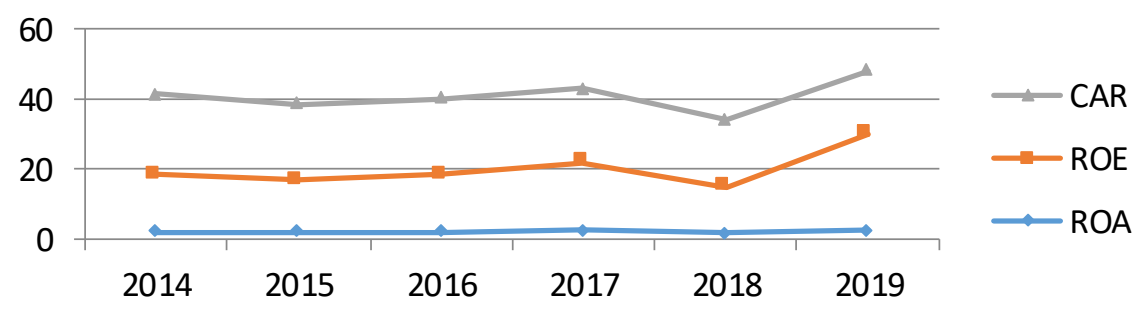

Grafik 1. Pertumbuhan BUS di Indonesia

Sumber.: Data Penelitian, 2020

Setelah melihat Grafik 1, dapat dinyatakan bahwa pertumbuhan dan perkembangan Bank Umum Syariah (BUS) di Indonesia setiap tahunnya cenderung mengalami kenaikan fluktuatif. Berarti disini bank syariah mendapat perhatian dan respon yang baik dari masyarakat, perusahaan, maupun perbankan syariah. Namun pada tahun tertentu telah terjadi penurunan, hal ini perlu dikaji lagi agar pada tahun-tahun berikutnya dapat menjadi evaluasi untuk meningkatkan kinerja keuangannya.

Signaling theory adalah gerak laku yang diambil manajemen perusahaan yang digunakan sebagai pedoman bagi para investor untuk menilai prospek pada suatu perusahaan. Prospek suatu perusahaan dapat dilihat dari nilai perusahaan. Jika nilai perusahaan tinggi maka akan memberi sinyal kepada investor untuk berinvestasi di perusahaan tersebut. Hal tersebut merupakan sinyal positif bagi 
suatu perusahaan (Najmudin, 2011). Tujuan teori sinyal adalah untuk mempengaruhi keputusan investasi investor, yang nantinya akan mempengaruhi nilai perusahaan di masa yang akan datang. Teori sinyal menunjukkan bahwa pengeluaran investasi memberikan sinyal positif bagi pertumbuhan perusahaan di masa depan, sehingga meningkatkan harga saham sebagai indikator nilai perusahaan. Perusahaan dengan prospek yang baik akan berusaha membujuk investor dengan membuktikan bahwa keuntungan perusahaan yang tinggi berarti kemakmuran perusahaan yang baik, sehingga investor dapat membangkitkan minat dan merespon secara positif, dan harga saham perusahaan akan naik (Fitria \& Rochmah, 2017).

Stakeholder theory juga menjelaskan tentang hubungan antara perusahaan dan pemangku kepentingan, yang didefinisikan sebagai aturan dan praktik atas nilai-nilai yang sesuai dengan ketentuan hukum yang ada. Stakeholder mempunyai hak yaitu untuk memperoleh informasi operasional perusahaan yang digunakan sebagai salah satu dasar dalam pengambilan keputusan, sehingga tidak hanya diukur pada laporan keuangan saja sebagai skala ekonomi, namun juga lebih memperhatikan banyak faktor lain seperti sosial terhadap para pemangku kepentingan, secara eksternal maupun internal (Asandimitra \& Ningrum, 2017). Pengungkapan CSR yang semakin baik oleh perusahaan maka membuat stakeholder dapat memberikan dukungan penuh kepada perusahaan atas segala aktivitas-aktivitasnya yang bertujuan untuk mendapatkan laba sesuai yang diharapkan dan meningkatkan kinerja perusahaan.

Kinerja perusahaan dapat dilihat dari tingkat profitabilitas perusahaan, semakin tinggi tingkat profitabilitas maka semakin tinggi pula kemampuan perusahaan dalam menghasilkan laba. Rasio keuntungan yang tinggi akan membuat investor tertarik untuk menanamkan modalnya di perusahaan. Kenaikan laba perusahaan akan mempengaruhi harga saham, dan harga saham akan naik (Husnan, 2001). Marjin laba yang tinggi mencerminkan kemampuan perusahaan untuk menciptakan return yang tinggi bagi pemegang saham. Perusahaan yang menguntungkan juga berkaitan dengan kemampuan perusahaan dalam membayar deviden, sehingga berdampak pada pertumbuhan nilai perusahaan. Peningkatan kinerja perusahaan juga akan meningkatkan nilai perusahaan. Hasil penelitianl sebelumnya yangl mendukung klaim ini adalah Sulistiyo \& Yuliana (2019), dan Safitri.et al..(2018).yang memperoleh hasil penelitian bahwal profitabilitas berpengaruh positifl signifikan lterhadap nilai lperusahaan. Rasio ROA digunakan sebagai indikator dalam mengukur keberhasilan perusahaan untuk memperoleh laba bagi para pemegang saham, sehingga dari pemaparan tersebut dapat diperoleh hipotesis sebagai berikut.

$\mathrm{H}_{1}$ : Semakin tinggi Return on Asset (ROA), maka nilai perusahaan akan meningkat.

ROE mencerminkan tingkat pengembalian investasi bagi para pemegang saham. Semakin tinggi ROE menunjukkan semakin efisiensi perusahaan menggunakan modal sendiri untuk menghasilkan laba atau keuntungan bersih (Ardimas, 2014). Menurut Analisa \& Wahyudi (2011), tingginya minat investor untuk menanamkan modalnya pada perusahaan dengan ROE yang tinggi akan meningkatkan harga saham. Maka, akan terjadi hubungan positif antara profitabilitas dengan efisiensi perusahaan dan harga saham dimana tingginya harga saham akan mempengaruhi nilai perusahaan. Hal ini didukung oleh 
penelitian dari Mufidah \& Purnamasari (2018), Suffah \& Riduwan (2016), dan Hasibuan et al. (2016).

$\mathrm{H}_{2}$ : Semakin tinggi Return on Equity (ROE), maka semakin tinggi nilai perusahaan.

Menurut Harahap (2015), rasio kecukupan modal (CAR) menunjukkan penilaian rasio kecukupan modal suatu bank untuk mendukung aset yang mengandung atau menimbulkan risiko, seperti pinjaman nasabah. Modal yang cukup sangat penting bagi bank untuk menutupi kerugian yang mungkin timbul akibat kegiatan usahanya. Semakin tinggi nilai rasio kecukupan modal akan meningkatkan nilai perusahaan dengan meningkatkan kepercayaan masyarakat. Rochmah \& Fitria (2017), Halimah \& Komariah (2017) mendukung penelitian terkait rasio kecukupan modal lterhadap nilai lperusahaan. Dari pemaparan tersebut maka diperoleh hipotesis sebagai berikut.

$\mathrm{H}_{3}$ : Semakin tinggi Capital Adequancy Ratio (CAR), maka nilai perusahaan akan meningkat.

Menurut Kasmir (2015), untuk mengukur kemampuan perusahaan untuk membayar kewajibannya, baik jangka pendek maupun jangka panjang ketika perusahaan dibubarkan (dilikuidasi) digunakan rasio solvabilitas/leverage. Teori sinyal membangun hubungan leverage dengan nilai perusahaan. Cash flow yang berlebihan oleh manajemen dapat dikendalikan oleh hutang. Maka diharapkan dapat menghindari investasi yang sia-sia dan akan meningkatkan nilai perusahaan. Peningkatan rasio hutang suatu perusahaan dibenarkan sebagai sinyal positif bagi investor dengan asumsi cash flow perusahaan di masa yang akan datang tentu akan terjaga, dan menunjukkan optimisme dari manajemen dalam melakukan investasi (Suffah \& Ridwan, 2016). Hutang yang digunakan secara efektif akan menghasilkan profit yang berdampak pada peningkatan nilai perusahaan. Hall..ini..didukung penelitianl..yang dilakukanl..oleh 1Safitri et al. (2018), Wulandari \& Wiksuana (2017), dapat dirumuskan hipotesis sebagai berikut.

$\mathrm{H}_{4}$ : Leverage berpengaruh kuat terhadap nilai perusahaan.

Dengan didukung profitabilitas yang baik maka memberikan dampak yang baik juga terhadap pengungkapan Islamic Social Reporting. Seperti penyataan yang diungkapkan oleh Zimmerman (1986), perusahaan yang memiliki profit yang tinggi, akan cenderung melakukan intervensi kebijakan. Sehingga, perusahaan tersebut akan terpacu untuk mengungkapkan informasi yang lebih rinci dalam laporan keuangan perusahaan. Salah satu cara perusahaan untuk meningkatkan nilai perusahaan yaitu dengan cara meningkatkan nilai Return on Assets (ROA). Selain melihat tingkat profitabilitas, investor juga dapat memperoleh kepercayaan dari masyarakat, yaitu perusahaan tidak hanya harus memperhatikan laba saja, tetapi juga memperhatikan dampak lingkungan di sekitarnya. Hal tersebut sejalan dengan teori stakeholder yang menyatakan bahwa tanggung jawab sosial perusahaan kepada stakeholders akan semakin memperkuat kemitraan antara kedua belah pihak, sehingga dapat meningkatkan produksi pada perusahaan (Mufidah \& Purnamasari, 2018). Berdasarkan pemaparan, dapat disimpulkan bahwa Islamic Social Reporting (ISR) mampu memoderasi pengaruh profitabilitas terhadap nilai. Hal ini didukung penelitian Sulistiyo \& Yuliana (2019), Mufidah \& Purnamasari (2018). Maka penelitian ini dapat dirumuskan ke dalam hipotesis berikut. 
$\mathrm{H}_{5}$ : Pengungkapan Islamic Social Reporting (ISR) mampu memoderasi pengaruh Return on Asset (ROA) terhadap nilai perusahaan.

Teori legitimasi menitikberatkan pada interaksi antara perusahaan dengan masyarakat yang didasarkan pada "kontrak sosial" yang terjadi antara perusahaan dengan masyarakat tempat perusahaan beroperasi dan menggunakan sumber daya ekonomi. Penggunaan teori legitimasi dalam penelitian ini mengandung arti bahwa ISR yang diterapkan oleh perusahaan bertujuan untuk mendapatkan nilai positif dan legitimasi dari masyarakat. Artinya apabila perusahaan memperoleh legitimasi dari masyarakat, maka perusahaan dapat terus bertahan dan berkembang di masyarakat serta memperoleh manfaat dimasa yang akan datang terutama dengan dukungan kinerja perusahaan yang baik. ISR yang baik pada perbankan syariah memiliki tingkat pengungkapan yang lebih luas. Pengungkapan yang semakin luas akan memberikan sinyal positif kepada pihak-pihak yang berkepentingan terhadap perusahaan (stakeholder) maupun para pemegang saham perusahaan (shareholder). Semakin luas informasi yang disampaikan kepada stakeholder dan shareholder maka akan semakin memperbanyak informasil yang diterima mengenai perusahaan. Hal ini akan menimbulkan kepercayaan stakeholder dan shareholder kepada perusahaan. Kepercayaan ini ditunjukkan stakeholder dengan diterimanya produk-produk perusahaan sehingga akan meningkatkan nilai perusahaan di masa yang akan datang. Hal ini didukung penelitian dari Fitriyah et al. (2016) dan Rozzi \& Bahjatullah (2020). Maka dapat dirumuskan ke dalam hipotesis berikut.

$\mathrm{H}_{6}$ : Pengungkapan Islamic Social Reporting (ISR) mampu memoderasi pengaruh Return on Equity (ROE) terhadap nilai perusahaan.

Rasio kecukupan modal atau Capital Adequacy Ratio (CAR) mencerminkan kemampuan bank untuk menutup risiko kerugian dari aktivitas yang dilakukannya dan kemampuan bank dalam mendanai kegiatan operasionalnya (Idroes, 2008). Apabila bank dapat meningkatkan cadangan kas yang tersedia untuk kegiatan operasinya, maka akan membuka lebih banyak kesempatan bagi bank untuk meningkatkan profitabilitasnya. Jika profitabilitas baik maka status keuangan perusahaan juga baik. Hal ini dapat meningkatkan kepercayaan investor dalam berinvestasi. Rasio kecukupan modal diyakini berdampak pada Islamic Social Report (ISR). Hal ini didukung oleh penelitian Sulistiyo \& Yuliana (2019) dan Fitriyah et al. (2016). Maka penelitian ini dapat dirumuskan ke dalam hipotesis berikut.

$\mathrm{H}_{7}$ : Pengungkapan Islamic Social Reporting (ISR) mampu memoderasi pengaruh Capital Adequancy Ratio (CAR) terhadap nilai perusahaan.

Menurut Kasmir (2015), rasio yang digunakan untuk mengukur seberapa aktiva perusahaan dibiayai oleh utang disebut dengan leverage. Menurut Ernawati dan Widyawati (2015), rasio leverage yang lsemakin tinggi menunjukkan bahwa perusahaan tersebut tidak solvabel, artinya total hutang yang dimiliki lebih besar dibandingkan dengan jumlah total lassetnya. Berdasarkan teori stakeholder, pengungkapan tanggung jawab sosial perlu dilakukan perusahaan kepada para pemangku kepentingan (stakeholder). Penerapan CSR tidak hanya dianggap sebagai cost, namun juga dianggap sebagai bentuk salah satu investasi pada perusahaan. Tingkat pelaksanaan CSR yang rendah dilakukan oleh perusahaan tersebut akan menghambat perusahaan dalam memperoleh kepercayaan dalam 
pendanaan eksternal yaitu seperti leverage (Asandimitra \& Ningrum, 2017). Adanya CSR akan memberikan kemudahan bagi suatu perusahaan untuk mendapatkan pendanaan dari luar dan akan digunakan untuk meningkatkan nilai perusahaannya. Hal ini didukung oleh penelitian Wulandari \& Wiksuana (2017) dan Susilaningrum (2019)..Maka penelitian ini dapat merumuskan ke dalam hipotesis berikut.

$\mathrm{H}_{8}$ : Pengungkapan Islamic Social Reporting (ISR) mampu memoderasi pengaruh Leverage terhadap nilai perusahaan.

\section{METODE PENELITIAN}

Jenis penelitian ini menggunakan metode penelitian kuantitatif dengan menggunakan alat statistik dan pengujian hipotesis. Data yang digunakan dalam penelitian ini meliputi data sekunder berupa data tahunan BUS yaitu periode 2014-2019 yang diperoleh dari Annual Report yang dirilis oleh perusahaan masingmasing yang berkaitan dengan penelitian ini. Populasinya adalah seluruh bank umum syariah di Indonesia berjumlah 14 kurun waktu 2014-2019. Teknik pengambilan sampel menggunakan purposive sampling dan didapatkan 11 bank umum syariah. Variabel dependen adalah sistem kinerja keuangan bank syariah adalah dengan rasio $\mathrm{ROA}, \mathrm{ROE}, \mathrm{CAR}$, dan Leverage.

ROA $=\frac{\text { Laba sebelum Bunga dan Pajak }}{\text { Total aktiva }}$

ROE $=\frac{\text { Laba sebelum Bunga dan Pajak }}{\text { Total Ekuitas }}$

$\mathrm{CAR}=\frac{\text { Equity Capital }- \text { Fixed Asset }}{\text { Total Loans }+ \text { Securities }} \times 100 \%$

Debt to Equity Ratio (DER) $=\frac{\text { Total utang (debt) }}{\text { Ekuitas (Equity) }}$

Dalam penelitian ini variabel dependen yang digunakan adalah nilai perusahaan yang diproksikan dengan Price to Book Value (PBV).

$$
\mathrm{PBV}=\frac{\text { Harga Pasar Per Lembar Saham }}{\text { Nilai Buku Per Lembar Saham }}
$$

Variabel moderasi yang digunakan adalah Islamic Social Reporting (ISR). Pengungkapan Islamic Social Reporting (ISR) berasal dari laporan tahunan Bank Umum Syariah 2014-2019. Berikut rumus yang digunakan untuk menghitung disclosure level setelah scoring (pemberian nilai) pada indeks ISR selesai dilakukan.

$$
\text { Disclosure level }=\frac{\text { Jumlah skor disclosure yang dipenuhi }}{\text { Jumlah Skor Maksimum }}
$$

Analisis data yang digunakan adalah analisis statistik deskriptif dan analisis statistik inferensial. Teknik analisis data diawali dengan pra-analisis data yaitu uji asumsi klasik untuk dapat menghindarkan dari bias hasil penelitian. Setelah itu, dilanjutkan dengan uji analisis regresi moderasi, uji koefisien determinasi (uji R2), uji kelayakan model (uji F), dan uji signifikansi parameter individual (uji t) menggunakan perangkat Eviews 10. Pengujian terhadap analisis regresi menggunakan analisis regresi moderasi murni (pure moderator) dilakukan dengan membuat regresi interaksi, tetapi variabel moderator tidak berfungsi sebagai variabel bebas (Ghozali, 2017). Uji R2 dapat dilihat melalui nilai Adjusted R2 pada hasil Model Summary regresi. Uji F dapat dilihat melalui hasil ANOVA regresi, 
apabila nilai Sig. F kurang dari tingkat signifikansi 0,05 berarti variabel independen dan variabel moderasi yang digunakan dapat memprediksi model secara simultan. Uji t digunakan untuk menguji variabel independen penelitian secara individual memengaruhi variabel dependen atau dalam arti lain yaitu menguji hipotesis penelitian, apabila nilaiSig. kurang dari tingkat signifikansi 0,05 berarti variabel independen dan variabel moderasi dapat memprediksi variabel dependen serta dapat menjawab apakah hipotesis diterima atau ditolak. Persamaan analisis regresi Moderated Regression Analysisl (MRA) yang digunakan penelitian ini sebagai berikut.

$$
\begin{aligned}
& Y i=\alpha+\beta_{1} X_{1}+\beta_{2} X_{2}+\beta_{3} X_{3}+\beta_{4} X_{4}+\beta_{5} Z i+\beta_{6} X_{1} * Z i+\beta_{7} X_{2} * Z i+\beta_{8} X_{3} * Z i+\beta_{9} \\
& \mathrm{X}_{4} * \mathrm{Zi}
\end{aligned}
$$

Keterangan :

$$
\begin{array}{ll}
\mathrm{Yi}_{\mathrm{i}} & =\text { Nilai Perusahaan } \\
\mathrm{X}_{1} & =\mathrm{ROA} \\
\mathrm{X}_{2} & =\mathrm{ROE} \\
\mathrm{X}_{3} & =\mathrm{CAR} \\
\mathrm{X}_{4} & =\text { Leverage } \\
\mathrm{Zi} & =\text { Islamic Social Reporting (ISR) } \\
\mathrm{X}_{1} * \mathrm{Zi} & =\text { Interaksi antara ROA dengan ISR } \\
\mathrm{X}_{2} * \mathrm{Zi} & =\text { Interaksi ROE dengan ISR } \\
\mathrm{X}_{3} * \mathrm{Zi} & =\text { Interaksi CAR dengan ISR } \\
\mathrm{X}_{4} * \mathrm{Zi} & =\text { Interaksi Leverage dengan ISR } \\
\alpha & =\text { Parameter konstanta } \\
\beta & =\text { Koefisien regresi berganda }
\end{array}
$$

\section{HASIL DAN PEMBAHASAN}

Teknik pengambilan sampel menggunakan purposive sampling. Purposive sampling adalah teknik penentuan sampel dengan pertimbangan tertentu.

\section{Tabel 1. Kriteria Sampel}

\begin{tabular}{clc}
\hline No. & \multicolumn{1}{c}{ Kriteria Pengambilan Sampel } & Jumlah \\
\hline 1. & BUS beroperasi secara nasionaldan terdaftar di Bank Indonesia & 14 \\
2. & $\begin{array}{l}\text { BUS yang tidak beroperasi secara nasional dan berturut-turut } \\
\text { periode penelitian 2014-2020, yaitu: }\end{array}$ & $(2)$ \\
3. & $\begin{array}{l}\text { BUS yang tidak menerbitkan laporan tahunan dan CSR secara } \\
\text { berturut-turut periode penelitian 2014-2020. }\end{array}$ & $(1)$ \\
& Jumlah sampel yang memenuhi kriteria & 11 \\
& Tahun pengamatan & 6 \\
& Total sampel $(6 \times 6)$ & 66 \\
\hline
\end{tabular}

Sumber: Data Penelitian, 2021

Variabel yang digunakan dalam penelitian ini adalah variabel fundamental yang diukur dengan variabel independen yaitu $\operatorname{ROA}\left(X_{1}\right), \operatorname{ROE}\left(X_{2}\right), \operatorname{CAR}\left(X_{3}\right)$, Leverage $\left(\mathrm{X}_{4}\right)$, variabel dependen PBV $(\mathrm{Y})$ dan variabel moderasi yaitu ISR $(\mathrm{Z})$. Dengan hasil output dari analisis statistik deskriptif berikut dapat dilihat nilai mean, minimum, maximum, dan standar deviasi. 
TUNJUNGSARI, S., \& IRKHAMI, N.

Tabel 2. Uji Statistik Deskriptif

\begin{tabular}{lcccccc}
\hline & $\mathrm{X}_{1}$ & $\mathrm{X}_{2}$ & $\mathrm{X}_{3}$ & $\mathrm{X}_{4}$ & $\mathrm{Y}$ & $\mathrm{Z}$ \\
\hline Mean & 0,950 & 3,143 & 20,379 & 2,826 & 4,166 & 0,769 \\
Median & 0,590 & 3,350 & 18,810 & 1,780 & 1,495 & 0,770 \\
Maximum & 13,600 & 36,500 & 44,600 & 30,470 & 69,640 & 0,900 \\
Minimum & $-10,770$ & $-94,010$ & 11,510 & 0,370 & 0,010 & 0,560 \\
Std. Dev. & 3,512 & 17,717 & 7,369 & 4,103 & 10,686 & 0,080 \\
\hline
\end{tabular}

Sumber: Data Penelitian, 2021

Hasil analisis menunjukkan bahwa pada variabel profitabilitas yang diproksikan Return On Asset (ROA) sebagai $\mathrm{X}_{1}$ tertinggi dimiliki oleh BTPN Syariah sebesar 13,6 pada periode 2019 dan ROA paling rendah dimiliki oleh Bank Panin Syariah sebesar -10,77 tahun 2017. Mean atau nilai rata-rata dari ROA adalah 0,95. Standar deviasi ROA adalah 3,512. Return On Equity (ROE) sebagai $\mathrm{X}_{2}$ tertinggi dimiliki BTPN Syariah sebesar 36,5 periode 2017 dan ROE paling rendah dimiliki Bank Panin Syariah sebesar -94,01 tahun 2017. Mean dari ROE adalah 3,143. Standar deviasi ROE adalah 17,717. CAR sebagai $X_{3}$ nilai tertinggi dimiliki BTPN Syariah sebesar 44,6 tahun 2019 dan CAR terendah dimiliki Bank Panin Syariah sebesar 11,51 tahun 2018. Mean dari CAR adalah 20,379. Standar deviasi dari CAR adalah 7,369. Leverage (DER) sebagai $\mathrm{X}_{4}$ nilai tertinggi dimiliki oleh Bank Panin Syariah sebesar 30,47 pada tahun 2019 dan DER terendah dimiliki oleh BCA Syariah sebesar 0,37 tahun 2018. Mean dari DER adalah 2,826. Standar deviasi dari DER adalah 4,103. Nilai perusahaan (PBV) sebagai Y nilai paling tinggi dimiliki oleh Bank Panin Syariah sebesar 69,64 periode 2016 dan PBV paling rendah dimiliki oleh Bank Mega Syriah dan BRI Syariah sebesar 0,01 tahun 2016. Mean dari PBV adalah 4,166. Standar deviasi PBV adalah 10,686. Pengungkapan Islamic Social Reporting (ISR) sebagai Z paling tinggi dimiliki oleh Bank Muamalat Indonesia sebesar 0,9 pada tahun 2019 dan ISR paling rendah dimiliki oleh Bank Victoria Syariah tahun 2014 sebesar 0,56. Mean dari ISR adalahl 0,769. Standar deviasi ISR adalah 0,080.

Selanjutnya dilakukan uji asumsi klasik terhadap data penelitian untuk dapat menghasilkan model regresi yang tidak bias. Hasil uji asumsi klasik disajikan berikut ini.

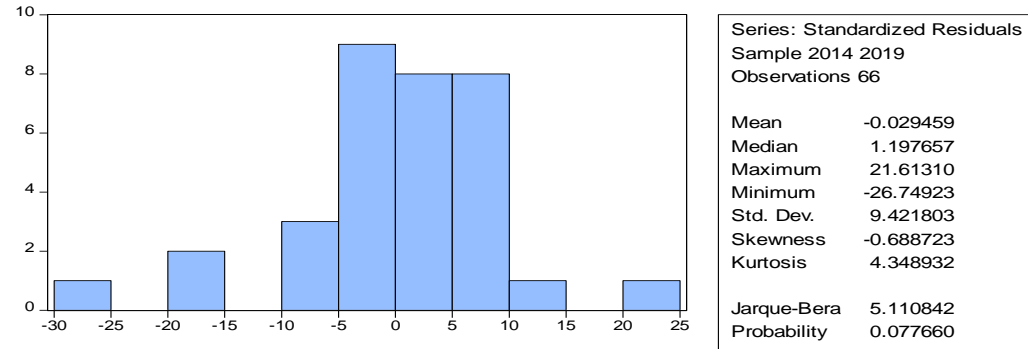

Sumber: Data Penelitian, 2021

Gambar 1. Hasil Uji Normalitas

Uji normalitas dilakukan untuk mengetahui apakah model regresi, residual atau variabel pengganggu berdistribusi normal atau tidak (Ghozali, 2017). Uji ini menggunakan uji statistik histogram Jarque-Bera. Residual berdistribusi normal jika memiliki nilai probability yang lebih besar dari p-value 0,05 . Berdasarkan data tersebut, nilai probability sebesar 0,77 >0,05, yang artinya data tersebut dinyatakan normal. 


\section{Tabel 3. Hasil Uji Autokorelasi}

\begin{tabular}{ccccc}
\hline Variable & Coefficient & Std. Error & t-Statistic & Prob. \\
\hline RESID01(-1) & 0,051 & 0,142 & 0,358 & 0,721 \\
\hline Sumber: Data Penelitian 2021 & & &
\end{tabular}

Sumber: Data Penelitian, 2021

Pengujian autokorelasi dilakukan untuk menguji apakah dalam model regresi linear ada korelasi antara kesalahan pengganggu pada periode $t$ dengan kesalahan pengganggu pada periode t-1 (sebelumnya). Dalam penelitian ini menggunakan nilai statistik Wooldgridge Test, untuk mengetahui ada tidaknya autokorelasi. Berdasarkan data tersebut, variabel terbebas dari autokorelasi dikarenakan hasil Wooldgridge Test menunjukkan bahwa probability sebesar 0,721 > 0,05 .

Tabel 4. Hasil Uji Auxiliary Regression

\begin{tabular}{lr}
\hline$R$ Squared ROA & 0,593 \\
$R$ Squared ROE & 0,635 \\
$R$ Squared CAR & 0,271 \\
$R$ Squared DER & 0,382 \\
$R$ Squared ROA*ISR & 0,412 \\
$R$ Squared ROE*ISR & 0,442 \\
$R$ Squared CAR*ISR & 0,413 \\
$R$ Squared DER*ISR & 0,387 \\
$R$ Squared PBV & 0,773 \\
\hline
\end{tabular}

Sumber: Data Penelitian, 2021

Uji Multikolonieritas bertujuan untuk menguji apakah model regresi ditemukan adanya korelasi antar variabel bebas (independen). Model regresi yang baik seharusnya tidak terjadi korelasi diantara variabel independen. Berdasarkan Tabel 4, dapat kita lihat nilai $R$-Squared antar variabel independen tidak melebihi $R$-Squared dari model regresi utama sehingga pada model penelitian ini tidak terdapat masalah multikolinieritas.

\section{Tabel 5. Hasil Uji Glejser}

\begin{tabular}{ccccc}
\hline Variable & Coefficient & Std. Error & t-Statistic & Prob. \\
\hline C & $-1,585$ & 2,799 & $-0,566$ & 0,575 \\
X1 & $-3,849$ & 3,645 & $-1,055$ & 0,298 \\
X2 & 0,974 & 1,155 & 0,842 & 0,405 \\
X3 & 0,195 & 0,538 & 0,362 & 0,718 \\
X4 & $-1,382$ & 4,798 & $-0,288$ & 0,775 \\
X1Z & 4,86 & 4,401 & 0,928 & 0,359 \\
X2Z & $-1,077$ & 1,428 & $-0,754$ & 0,455 \\
X3Z & $-0,326$ & 0,646 & $-0,504$ & 0,616 \\
X4Z & 2,256 & 6,172 & 0,365 & 0,716 \\
AR(1) & 0,302 & 0,174 & 1,732 & 0,092 \\
R-squared. & 0,421 & & & $-1,948$
\end{tabular}

Sumber: Data Penelitian, 2020

Berdasarkan Tabel 5, dengan uji Glejser, dapat dilihat bahwa nilai probability dari semua variabel independen terhadap absolute residuals melebihi nilai $p$-value 0.05 , sehingga dapat disimpulkan bahwa tidak terjadi masalah heteroskedastisitas. Uji asumsi klasik telah menunjukkan bahwa data penelitian terhindar dari bias, sehingga dapat menghasilkan model regresi yang baik. Hasil analisis regresi moderasi disajikan pada Tabel 6 berikut. 
Tabel 6. Hasil Analisis Regresi Linier Berganda

\begin{tabular}{ccccc}
\hline Variable & Coefficient & Std. Error & $t$-Statistic & Prob. \\
\hline C & 5,526 & 2,395 & 2,306 & 0,027 \\
X1 & 1,914 & 0,637 & 3,005 & 0,004 \\
X2 & $-0,879$ & 0,198 & $-4,437$ & 0,000 \\
X3 & 0,152 & 0,106 & 1,438 & 0,159 \\
X4 & $-3,415$ & 2,713 & $-1,258$ & 0,216 \\
X1Z & $-2,106$ & 0,924 & $-2,277$ & 0,028 \\
X2Z & 1,10 & 0,242 & 4,544 & 0,000 \\
X3Z & $-0,183$ & 0,127 & $-1,436$ & 0,159 \\
X4Z & 4,202 & 3,345 & 1,256 & 0,217 \\
AR(1) & 0,561 & 0,187 & 2,993 & 0,005 \\
R-squared. & 0,773 & & & 4,664 \\
Adjusted.R-squared & 0,651 & & & 5,123 \\
S.E. of.regression & 3,368 & & & 397,169 \\
F-statistic. & 6,306 & & & 2,329 \\
Prob(F-statistic). & 0,000 & & & \\
\hline Sumber. Data Pen & & &
\end{tabular}

Sumber: Data Penelitian, 2021

Nilai konstanta (C) adalah -5.526, mempunyai arti jika variabel independen dianggap konstan, maka akan menurunkan nilai perusahaan sebesar 5.526. Koefisien regresi variabel profitabilitas (ROA) sebesar 1,914 yang berarti apabila profitabilitas (ROA) ada percepatan 1 poin maka nilai perusahaan akan ada kenaikan sebesar 1,914 poin. Koefisien regresi variable profitabilitas (ROE) adalah $-0,879$ yang artinya jika profitabilitas (ROE) ada percepatan 1 poin maka nilai perusahaan akan ada penurunan sebesar 0,879 poin. Koefisien regresi dari variabel kecukupan modal adalah 0,152 yang berarti jika kecukupan modal ada percepatan 1 poin maka nilai perusahaan akan ada kenaikan sebesar 0,152 poin. Koefisien regresi dari variabel leverage adalah -3,415 yang berarti jika leverage ada percepatan 1 poin maka nilai perusahaan akan ada penurunan sebesar 3,415 poin. Koefisien regresi variable ROA dengan ISR sebesar -2,106 yang dapat diartikan bahwa apabila ROA dengan ISR mengalami percepatan 1 poin maka nilai perusahaan akan ada penurunan sebesar 2,106 poin. Koefisien regresi variabel ROE dengan ISR sebesar 1,100 yang dapat diartikan bahwa apabila ROE dengan ISR mengalami percepatan 1 poin maka nilai perusahaan akan ada kenaikan sebesar 1,100 poin. Koefisien regresi variabel kecukupan modal dengan ISR sebesar -0,183 yang dapat diartikan bahwa apabila kecukupan modal dengan ISR mengalami percepatan 1 poin maka nilai perusahaan akan ada penurunan sebesar 0,183 poin. Koefisien regresi variabel leverage dengan ISR sebesar 4,202 yang dapat diartikan bahwa apabila leverage dengan ISR mengalami percepatan 1 poin maka nilai perusahaan akan ada kenaikan sebesar 4,202 poin.

Berdasarkan hasil yang telah diuji menunjukkan nilai probability (ROA) sebesar 0,027. Nilai probability dibawah 0,05 maka ROA secara parsial akan mempengaruhi tingkat nilai perusahaan. Nilai probability (ROE) sebesar 0,000. Nilai probability dibawah 0,05, maka ROE secara parsial akan mempengaruhi tingkat nilai perusahaan. Nilai probability (CAR) sebesar 0,159. Nilai probability diatas 0,05, maka kecukupan modal secara parsial tidak akan mempengaruhi tingkat nilai perusahaan. Nilai probability (DER) sebesar 0,216. Nilai probability diatas 0,05, maka leverage secara parsial tidak akan mempengaruhi tingkat nilai 
perusahaan. Nilai probability sebesar 0,028. Nilai probability dibawah 0,05, maka ISR memperkuat pengaruh profitabilitas (ROA) terhadap tingkat nilai perusahaan. Nilai probability sebesar 0,000. Nilai probability dibawah 0,05, maka ISR memperkuat pengaruh profitabilitas (ROE) terhadap tingkat nilai perusahaan. Nilai probability sebesar 0,159. Nilai probability diatas 0,05 maka ISR memperlemah pengaruh kecukupan modal terhadap tingkat nilai perusahaan. Nilai probability sebesar 0,217. Nilai probability diatas 0,05 maka ISR memperlemah pengaruh leverage terhadap tingkat nilai perusahaan.

Dari hasil yang telah diuji, nilai probability F-statistic sebesar 0,000. Karena nilai probability dibawah 0,05, diartikan bahwa variabel profitabilitas (ROA dan ROE), kecukupan modal, leverage, dan ISR secara bersama atau simultan berpengaruh terhadap nilai perusahaan. Dari hasil yang telah diuji nilai Adjusted $R$-squared sebesar 0,651. Menunjukkan bahwa 65,12\% nilai perusahaan dapat dipengaruhi oleh variabel profitabilitas (ROA dan ROE), kecukupan modal, dan leverage sedangkan 34,88\% nilai perusahaan dipengaruhi variabel lain yang tidak ada dalam riset ini, seperti variabel komisaris independen, variabel komite audit, variable kepemilikan manajerial, ataupun variabel lainnya.

Hipotesis pertama menyatakan semakin tinggi Return on Asset (ROA), maka nilai perusahaan akan meningkat. Berdasarkan hasil pengujian, pengaruh ROA terhadap nilai perusahaan diperoleh nilai koefisien sebesar 1,914, nilai probability sebesar 0,004 dibawah 0,05 $(0,004<0,05)$. Dari hasil data statistik dapat dinyatakan bahwa hipotesis 1 diterima dan dapat disimpulkan bahwa variabel ROA memiliki pengaruh positif dan signifikan terhadap nilai perusahaan. Hasil riset ini sejalan dengan penelitian dari Kalbuana et al. (2017), Sulistiyo \& Yuliana (2019), Mufidah \& Purnamasari (2018), dan Safitri et al. (2018) menunjukkan bahwa semakin tinggi tingkat profitabilitas yaitu Return on Asset (ROA) maka semakin tinggi pula tingkat nilai perusahaan BUS di Indonesia. Hal ini terjadi dikarenakan rasio profitabilitas (ROA) yang tinggi, akan membuat para investor tertarik untuk menginvestasikan modalnya ke dalam bank syariah. Sehingga kemampuan bank syariah untuk menghasilkan keuntungan bagi pemegang saham meningkat dan mempengaruhi nilail perusahaan yang juga meningkat.

Hipotesis kedua menyatakan semakin tinggi Return on Equity (ROE), maka semakin tinggi nilai perusahaan. Berdasarkan hasil pengujian, pengaruh ROE terhadap nilai perusahaan menunjukkan bahwa nilai koefisien sebesar $-0,879$, nilai probability sebesar 0,000 dibawah $0,05(0,000<0,05)$. Dari hasil data statistik dapat dinyatakan bahwa hipotesis 2 diterima dan dapat disimpulkan bahwa variabel ROE memiliki pengaruh negatif dan signifikan terhadap nilai perusahaan. Hasil penelitian ini bertentangan dengan penelitian dari Mufidah \& Purnamasari (2018), Suffah \& Riduwan (2016), Hasibuan et al. (2016), dan Rudangga \& Sudiarta (2016) yang menyatakan bahwa profitabilitas (ROE) berpengaruh positif terhadap nilai perusahaan dimana semakin tinggi ROE menunjukkan semakin efisiensi perusahaan menggunakan modal sendiri untuk menghasilkan laba atau keuntungan bersih. Dan hal inilah yang dapat meningkatkan nilai perusahaan sehingga investor juga lebih tertarik untuk menanam saham pada bank syariah. Namun pada penelitian ini dikatakan bahwa profitabilitas (ROE) berpengaruh negatif terhadap nilai perusahaan dilihat dari hasil penelitian dikarenakan BUS 
memiliki rata-rata profitabilitas (ROE) yang rugi sedangkan nilai perusahaan ratarata memiiki nilai yang stagnan.

Hipotesis ketiga menyatakan semakin tinggi Capital Adequancy Ratio (CAR), maka nilai perusahaan akan meningkat. Berdasarkan hasil pengujian, pengaruh CAR terhadap nilai perusahaan menunjukkan bahwa nilai koefisien sebesar 0,153, nilai probability sebesar 0,159 diatas 0,05 $(0,159>0,05)$. Dari hasil data statistik sebelumnya dapat dinyatakan bahwa hipotesis 3 ditolak dan dapat disimpulkan bahwa variabel CAR tidak berpengaruh signifikan terhadap nilai perusahaan BUS di Indonesia periode2014-2019. Hasil penelitian ini tidak sejalan dengan penelitian dariSulistiyo \& Yuliana (2019), Rochmah \& Fitria (2017) dan Halimah \& Komariah (2017) menunjukkan bahwa CAR memiliki pengaruh positif signifikan terhadap nilai perusahaan. Hal ini terjadi dikarenakan ketentuan pemerintah yang mewajibkan bank memiliki Capital Adequacy Ratio minimal 8\%. Hal ini menyebabkan bank pasti memilki nilai Capital Adequacy Ratio tinggi yang justru menyebabkan turunnya nilai perusahaan. Meskipun bank memiliki modal yang tinggi dan tingkat Capital Adequacy Ratio yang tinggi, bila tidak diimbangi dengan investasi dan penyaluran dana yang baik, Capital Adequacy Ratio tidak akan berpengaruh banyak terhadap nilai perusahaan yang di proksikan dengan Price Book Value.

Hipotesis keempat menyatakan leverage berpengaruh kuat terhadap nilai perusahaan. Berdasarkan hasil pengujian, pengaruh DER terhadap nilai perusahaan menunjukkan bahwa nilai koefisien sebesar -3,415, nilai probability sebesar 0,216 dibawah 0,05 (0,216>0,05). Dari hasil data statistik dapat dinyatakan bahwa hipotesis 4 ditolak dan dapat disimpulkan bahwa variabel DER tidak berpengaruh signifikan terhadap nilai perusahaan. Hasil penelitian ini sejalan dengan penelitian dari Kalbuana et al. (2017), menunjukkan bahwa leverage memiliki pengaruh negatif tidak signifikan terhadap nilai perusahaan. Namun bertolak belakang dengan hasil penelitian Safitri et al. (2018), Wulandari \& Wiksuana (2017), Suffah \& Riduwan (2016), dan Farooq (2016), menunjukkan bahwa leverage berpengaruh terhadap nilai perusahaan. Hal ini terjadi karena tinggi rendahnya hutang yang dimiliki suatu perusahaan tidak akan mempengaruhi tingkat nilai perusahaan. Karena dalam ruang lingkup pasar modal di Indonesia pergerakan harga saham dan penciptaan nilai tambah perusahaan terjadi karena disebabkan oleh factor psikologis pasar. Tinggi rendahnya hutang tidak terlalu dilihat oleh investor karena investor lebih melihat bagaimana pihak manajemen perusahaan dalam menggunakan dana tersebut dengan efektif serta efisien untuk mencapai nilai tambah bagi perusahaan.

Hipotesis kelima penelitian $\left(\mathrm{H}_{5}\right)$ yaitu Pengungkapan Islamic Social Reporting (ISR) mampu memoderasi pengaruh Return on Asset (ROA) terhadap nilai perusahaan. Berdasarkan hasil uji MRA dapat diperoleh nilai koefisien regresi perkalian ROA dan ISR (ROA*ISR) sebesar -2,106, dengan nilai probability sebesar 0,028 dibawah $0,05(0,028<0,05)$. Dari hasil data statistik dapat dinyatakan bahwa hipotesis 5 diterima dan dapat disimpulkan bahwa ISR dapat lmemoderasi ROA terhadap nilai perusahaan. Hasil penelitian yang telah dilakukan sejalan dengan penelitian dari Sulistiyo \& Yuliana (2019), dan Damayanti (2018), menyatakan bahwa ISR mampu memoderasi ROA terhadap nilai perusahaan. Hal ini terjadi karena ketika stakeholders percaya terhadap perbankan syariah, maka mereka akan 
bersedia untuk mengivestasikan modalnya, modal tersebut jika dikelola secara efektif dan efisien maka akan menghasilkan keuntungan yang besar. Dengan semakin meningkatnya keuntungan, maka dapat meningkatkan nilai perusahaan.

Hipotesis keenam menyatakan pengungkapan Islamic Social Reporting (ISR) mampu memoderasi pengaruh Return on Equity (ROE) terhadap nilai perusahaan. Berdasarkan hasil uji MRA dapat diperoleh nilai koefisien regresi perkalian $\mathrm{ROE}$ dan ISR (ROE*ISR) sebesar 1,100, nilai probability sebesar 0,000 dibawah $0,05(0,000$ $<0,05)$. Daril hasil data statistik dapat dinyatakan bahwa hipotesis 6 diterima dan dapat disimpulkan bahwal variabel ISR mampu memoderasi pengaruh ROE terhadap nilai perusahaan. Hasil penelitian ini tidak sejalan dengan penelitian dari Fitriyah et al. (2016) menyatakan bahwa ISR tidak mampu memoderasi ROE terhadap nilai perusahaan. Dari hasil pengujian, bahwa ISR mampu memperkuat ataupun memperlemah pengaruh ROE terhadap nilai perusahaan. Hal ini terjadi dikarenakan pengungkapan ISR bank syariah yang baik, akan memperluas sinyal positif kepada stakeholder dan shareholder. Sehingga mampu menunjukkan pengaruhnya terhadap nilai perusahaan pada bank syariah dan dapat memoderasi pengaruh ROE terhadap nilai perusahaan.

Hipotesis 7 menyatakan pengungkapan Islamic Social Reporting (ISR) mampu memoderasi pengaruh Capital Adequancy Ratio (CAR) terhadap nilai perusahaan. Berdasarkan hasil uji MRA dapat diperoleh nilai koefisien regresi perkalian CAR dan ISR (CAR*ISR) sebesar -0,183, nilai probability sebesar 0,159 diatas 0,05 (0,159 $>0,05)$. Dari hasil data statistik dapat dinyatakan bahwa hipotesis 7 ditolak dan variabel ISR tidak mampu memoderasi pengaruh CAR terhadapnilai perusahaan. Hasil penelitian ini tidak sependapat dengan penelitian dari Sulistiyo \& Yuliana (2019) yang menyatakan ISR mampu memoderasi pengaruh CAR terhadap nilai perusahaan. Dari hasil pengujian menunjukkan bahwa ISR tidak memperkuat pengaruh CAR terhadap nilai perusahaan. Hal ini terjadi karena CAR tidak menunjukkan pengaruhnya terhadap nilai perusahaan bank syariah dan terdapat variabel lain yang mampu memoderasi pengaruh CAR terhadap nilai perusahaan.

Hipotesis kedelapan menyatakan Pengungkapan Islamic Social Reporting (ISR) mampu memoderasi pengaruh Leverage terhadap nilai perusahaan. Berdasarkan hasil uji MRA dapat diperoleh nilai koefisien regresi perkalian DER dan ISR (DER*ISR) sebesar 4,202, nilai probability sebesar 0,217 diatas 0,05 (0,217 > $0,05)$. Dari hasil data statistik dapat dinyatakan bahwa hipotesis 8 ditolak dan variabel ISR tidak mampu memoderasi pengaruh DER terhadap nilai perusahaan. Hasil penelitian ini sependapat dengan penelitian dari Susanti (2019) menyatakan tidak mampu dalam memoderasi pengaruh leverage. Dari hasil pengujian menunjukkan bahwa ISR tidak memperkuat pengaruh leverage terhadap nilai perusahaan. Hal ini terjadi karena leverage tidak menunjukkan pengaruhnya terhadap nilai perusahaan bank syariah dan terdapat variabel lain yang mampu memoderasi pengaruh leverage terhadap nilai perusahaan. Penggunaan utang yang tinggi dengan diimbangi dengan pelaksanaan ISR yang tinggi mampu mengurangi daya saing perusahaan sehingga berdampak pada penurunan nilai perusahaan. 


\section{SIMPULAN}

Berdasarkan riset, kesimpulan yang dapat diambil adalah variabel profitabilitas (ROA) memiliki pengaruh positif dan signifikan terhadap nilai perusahaan pada BUS di Indonesia periode 2014-2019, variabel profitabilitas (ROE) memiliki pengaruh negatif dan signifikan terhadap nilai perusahaan BUS di Indonesia periode 2014-2019, variabel kecukupan modal (CAR) tidak memiliki pengaruh signifikan terhadap nilai perusahaan BUS di Indonesia periode2014-2019, variabel leverage tidak memiliki pengaruh signifikan terhadap nilai perusahaan BUS di Indonesia periode 2014-2019, variabel ISR mampu memoderasi pengaruh profitabilitas (ROA) terhadap nilai perusahaan, variabel ISR mampu memoderasi pengaruh profitabilitas (ROE) terhadap nilai perusahaan, variabel ISR tidak mampu memoderasi pengaruh kecukupan modal (CAR) terhadap nilai perusahaan, dan variabel ISR tidak mampu memoderasi pengaruh leverage terhadap nilai perusahaan.

Berdasarkan kesimpulan dan keterbatasan yang ada, maka dapat disampaikan beberapa saran sebagai berikut. Bagi penanggung jawab di lingkup perbankan syariah. Hasil riset ini dapat dijadikan materi pertimbangan dalam merumuskan kebijakan dan ketetapan untuk meningkatkan nilai perusahaan. Penelitian yang telah dilakukan masih memiliki banyak kelemahan yang harus diperbaiki dan belum tuntas. Peneliti selanjutnya dapat mencari variabel lain atau menambahkan variabel lain yang dapat mempengaruhi nilai perusahaan, mencari variabel yang dapat memoderasi variabel independen terhadap variabel dependen yang terdapat dalam penelitian ini dan memperbaiki acuan teori rasio keuangan bank untuk memperoleh hasil penelitian yang maksimal. Pada penelitian yang telah dilakukan hanya menggunakan runtutan enam periode yakni periode 2014 sampai periode 2019. Bagi peneliti berikutnya diharapkan mampu menambah tahun periode pada penelitian tersebut, dengan begitu dapat memberi masukan atas hasil output pada penelitian yang lebih akurat dan sesuai dengan yang diinginkan.

\section{REFERENSI}

Analisa, Y., \& Wahyudi, S. (2011). Pengaruh Ukuran Perusahaan, Leverage, Profitabilitas dan Kebijakan Dividen Terhadap Nilai Perusahaan (Studi Pada Perusahaan Manufaktur yang Terdaftar di BEI Tahun 2006-2008). Skripsi Fakultas Ekonomi Dan Bisnis UNDIP.

Ardimas, W. dan W. (2014). Pengaruh Kinerja Keuangan dan Corporate Social Responsibility terhadap Nilai Perusahaan Pada Bank Go Public yang terdaftar di BEI. Research Methods and Organizational Studies, 231-238.

Asandimitra, N., \& Ningrum, U. N. (2017). Pengaruh Kinerja Keuangan, Struktur Modal dan Ukuran Perusahaan Terhadap Nilai Perusahaan dengan GCG dan CSR sebagai Variabel Moderating pada Perusahaan Peringkat Pertama ARA, ISRA dan Peringkat Emas Proper yang Listing di BEI Periode 2011-2015. Jurnal Ilmu Manajemen, 5.

Damayanti, A. R. (2018). Pengaruh Profitabilitas dan Maqashid Syariah Index terhadap Nilai Perusahaan Melalui Islamic Social Reporting sebagai Variabel Moderating (Studi Kasus Bank Umum Syariah Tahun 2012-2016). Skripsi Fakultas Ekonomi UIN Malang. 
Ernawati, D., \& Widyawati, D. (2015). Pengaruh Profitabilitas, Leverage, dan Ukuran Perusahaan Terhadap Nilai Perusahaan. Jurnal Ilmu Dan Riset Akuntansi, 4(4).

Farooq, M. A., \& Masood, A. (2016). Impact of Financial Leverage on Value of Firms : Evidence from Cement Sector of Pakistan. Research Jurnal of Finance and Accounting, 7(9), 73-77.

Fitria, A., \& Rochmah, S. A. (2017). Pengaruh Kinerja Keuangan Terhadap Nilai Perusahaan: Kebijakan Dividen Sebagai Variabel Moderating. Jurnal Ilmu Dan Riset Akuntansi, 6(3).

Fitriyah, N., Alamsyah, \& Pusparini, H. (2016). Kinerja Keuangan dalam Kerangka Maqashid Syariah: Pengaruhnya terhadap Nilai Perusahaan dengan Islamic Social Reporting sebagai Variabel Moderating (Studi pada Bank Umum Syariah di Indonesia). Jurnal Riset Akuntansi Aksiona, 15(2), 72-95.

Ghozali, I. (2017). Analisis Multivariat dan Ekonometrika Eviews 10 (2nd ed.). UNDIP. Halimah, S. N., \& Komariah, E. (2017). Pengaruh roa, car, npl, ldr, bopo terhadap nilai perusahaan bank umum. Jurnal Akuntansi, Ekonomi Dan Manajemen Bisnis, 5(1), 14-25.

Harahap, S. S. (2015). Analisis Kritis atas Laporan Keuangan. PT Raja Grafindo Persada.

Hasibuan, V., AR, M. D., \& NP, N. G. W. E. (2016). Pengaruh Leverage dan Profitabilitas terhadap Nilai Perusahaan (Studi pada Perusahaan Property dan Real Estate yang Terdaftar di Bursa Efek Indonesia Periode Tahun 20122015). Jurnal Administrasi Bisnis, 39(1), 139-147.

Husnan, S. (2001). Dasar-Dasar Teori Portofolio dan Analisis Sekuritas (Edisi 4). BPFE. Idroes, F. (2008). Manajemen Risiko Perbankan. PT Raja Grafindo Persada.

Kalbuana, N., Juniar, U., \& Amrizal. (2017). Pengaruh Profitabilitas, Leverage, dan Size Terhadap Nilai Perusahaan Pada Perusahaan Sektor Perbankan Yang Terdaftar di Bursa Efek Indonesia. Muhammadiyah University Press.

Kasmir. (2015). Analisis Laporan Keuangan. Rajawali Pers.

Mufidah, N., \& Purnamasari, P. E. (2018). Pengaruh Profitabilitas Terhadap Nilai Perusahaan Dengan Pengungkapan Corporate Social Responsibility dan Good Corporate Governance Sebagai Variabel Moderating. Jurnal Keuangan Dan Perbankan Syariah, 6(1), 64-82.

Najmudin. (2011). Manajemen Keuangan dan Akuntansi Syar'iyyah Modern. ANDI.

Rozzi, M. F., \& Bahjatullah, Q. M. (2020). Analisis Determinan Pelaporan Islamic Social Reporting (ISR) Pada Bank Umum Syariah Indonesia Tahun 2015-2019. MALIA: Journal of Islamic Banking and Finance, 4(2), 92-104.

Rudangga, I. N. G. G., \& Sudiarta, G. M. (2016). Pengaruh Ukuran Perusahaan, Leverage, dan Profitabilitas Terhadap Nilai Perusahaan. E-Jurnal Manajemen Universitas Udayana, 5(7), 4394-4422.

Safitri, Y., Abrar, \& Santoso, E. B. (2018). Peranan Corporate Social Responsibility Dalam Memoderasi Pengaruh Profitabilitas, Leverage dan Likuiditas Terhadap Nilai Perusahaan. Journal of Accounting, 4(4).

Suffah, R., \& Ridwan, A. (2016). Pengaruh Profitabilitas, Leverage, Ukuran Perusahaan dan Kebijakan Dividen Pada Nilai Perusahaan. Jurnal Ilmu Dan Riset Akuntansi, 5(3).

Sulistiyo, F., \& Yuliana, I. (2019). Pengaruh Profitabilitas dan Kecukupan Modal 
terhadap Nilai Perusahaan dengan Islamic Social Report ( ISR ) sebagai Variabel Moderasi ( Studi pada Bank Umum Syariah Indonesia Tahun 20142018 ). Jurnal Manajemen Dan Keuangan, 8(2), 238-255.

Susanti, R. (2019). Analisis Pengaruh Profitabilitas dan Leverage terhadap Nilai Perusahaan dengan Pengungkapan Islamic Social Reporting (ISR) sebagai Variabel Moderating (Studi Kasus Perusahaan yang Terdaftar di Jakarta Islamic Index (JII) Periose 2014-2018). SKRIPSI Fakultas Ekonomi Dan Bisnis Islam IAIN Salatiga.

Susilaningrum. (2019). Indonesian Journal of Islamic Economics Research. 1(2), 58-66. Watts, RL. dan Zimmerman, J. (1986). Positive Accounting Theory. Prentice-Hall. Wiksuana, I., \& Wulandari, N. (2017). Peranan Corporate Social Responsibility dalam Memoderasi Pengaruh Profitabilitas, Leverage dan Ukuran Perusahaan Terhadap Nilai Perusahaan. E-Jurnal Manajemen Universitas Udayana, 6(3). 